\title{
TPM2 Gene
}

National Cancer Institute

\section{Source}

National Cancer Institute. TPM2 Gene. NCI Thesaurus. Code C115001.

This gene plays a role in both muscle contraction and actin binding. 